\title{
Universe and Inner Self in Early Indian and Early Greek Thought
}

\author{
EDITED BY RICHARD SEAFORD
}


Edinburgh University Press is one of the leading university presses in the UK. We publish academic books and journals in our selected subject areas across the humanities and social sciences, combining cutting-edge scholarship with high editorial and production values to produce academic works of lasting importance. For more information visit our website: www.edinburghuniversitypress.com

(C) editorial matter and organisation Richard Seaford, 2016

(C) the chapters their several authors, 2016

Edinburgh University Press Ltd

The Tun - Holyrood Road

12(2f) Jackson's Entry

Edinburgh EH8 8PJ

Typeset in 10.5/13 Times New Roman by Servis Filmsetting Ltd, Stockport, Cheshire and printed and bound in Great Britain by CPI Group (UK) Ltd, Croydon CR0 4YY

A CIP record for this book is available from the British Library

ISBN 9781474410991 (hardback)

ISBN 9781474411004 (webready PDF)

ISBN 9781474411011 (epub)

The right of Richard Seaford to be identified as the editor of this work has been asserted in accordance with the Copyright, Designs and Patents Act 1988, and the Copyright and Related Rights Regulations 2003 (SI No. 2498). 